\title{
Determinants of Psychosocial Resilience Resources in Obese Pregnant Women with Threatened Preterm Labor-A Cross-Sectional Study
}

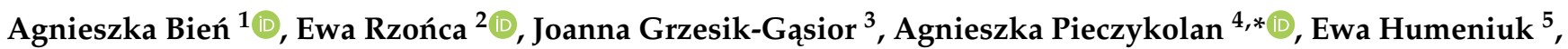 \\ Małgorzata Michalak $^{6}$, Grażyna Iwanowicz-Palus ${ }^{1}{ }^{[}$and Artur Wdowiak ${ }^{7}$ (])
}

1 Chair of Obstetrics Development, Faculty of Health Sciences, Medical University of Lublin, 4-6 Staszica St., 20-081 Lublin, Poland; agnesmbien@gmail.com (A.B.); spupalus@gmail.com (G.I.-P.)

2 Department of Obstetrics and Gynecology Didactics, Faculty of Health Sciences, Medical University of Warsaw, 14/16 Litewska St., 00-575 Warsaw, Poland; erzonca@wum.edu.pl

3 Department of Midwifery, Carpathian State College in Krosno, 6 Kazimierza Wielkiego St., 38-400 Krosno, Poland; joanna.grzesik@onet.pl

4 Faculty of Health Sciences, Students' Scientific Association at the Chair of Obstetrics Development, Medical University of Lublin, 4-6 Staszica St., 20-081 Lublin, Poland

5 Chair and Department of Psychology, Medical University of Lublin, 7 Chodźki St., 20-093 Lublin, Poland; ewa.humeniuk@umlub.pl

6 Department of Gynecology, Independent Public Teaching Hospital No. 4 in Lublin, 8 Jaczewskiego St., 20-954 Lublin, Poland; malgorzata.michalak93@gmail.com

Citation: Bień, A.; Rzońca, E.; Grzesik-Gąsior, J.; Pieczykolan, A.; Humeniuk, E.; Michalak, M.; Iwanowicz-Palus, G.; Wdowiak, A. Determinants of Psychosocial Resilience Resources in Obese Pregnant Women with Threatened Preterm Labor-A Cross-Sectional Study. Int. J. Environ. Res. Public Health 2021, 18, 10590. https:// doi.org/10.3390/ijerph182010590

Academic Editor: Paul B. Tchounwou

Received: 26 August 2021

Accepted: 5 October 2021

Published: 10 October 2021

Publisher's Note: MDPI stays neutral with regard to jurisdictional claims in published maps and institutional affiliations.

Copyright: (C) 2021 by the authors Licensee MDPI, Basel, Switzerland. This article is an open access article distributed under the terms and conditions of the Creative Commons Attribution (CC BY) license (https:// creativecommons.org/licenses/by/ $4.0 /)$.
7 Chair of Obstetrics and Gynaecology, Faculty of Health Sciences, Medical University of Lublin, 4-6 Staszica St., 20-081 Lublin, Poland; wdowiakartur@gmail.com

* Correspondence: aga.variable@gmail.com

\begin{abstract}
Background: The purpose of the study was to assess the level of such psychosocial resilience resources as self-efficacy, dispositional optimism, and health locus of control in pregnant women with obesity with threatened premature labor. Methods: The study was performed in the years 2017-2020 in a group of 328 pregnant women hospitalized due to threatened preterm labor and diagnosed with obesity before the pregnancy. The following instruments were applied: the Life Orientation Test, the Generalized Self-Efficacy Scale, and the Multidimensional Health Locus of Control Scale. Results: Obese pregnant women with threatened premature labor have a moderate level of generalized self-efficacy (28.02) and a moderate level of dispositional optimism (16.20). Out of the three health locus of control dimensions, the highest scores were recorded in the "internal control" subscale (26.08). Statistically significant predictors for the self-efficacy variable model included: satisfactory socio-economic standing ( $\beta=0.156 ; p=0.004)$, being nulliparous $(B=-0.191 ; p=0.002)$, and the absence of comorbidities $(\beta=-0.145 ; \mathrm{p}=0.008)$. Higher levels of dispositional optimism were found in women who were married $(B=0.381 ; p=0.000)$, reported a satisfactory socio-economic standing $(B=0.137 ; p=0.005)$, were between 23 and 27 weeks pregnant $(B=-0.231 ; p=0.000)$, and had no comorbidities $(B=-0.129 ; p=0.009)$. Conclusions: Generalized self-efficacy in obese women with threatened preterm labor is associated with satisfactory socio-economic standing, being nulliparous, and the absence of chronic disease. Dispositional optimism in obese pregnant women with threatened preterm labor is determined by their marital status, socio-economic standing, gestational age, and the absence of comorbidities.
\end{abstract}

Keywords: pregnancy; preterm labor; self-efficacy; life orientation; health locus of control

\section{Introduction}

Despite improvements in healthcare quality, there is an upward trend in the incidence of preterm deliveries (before 37 weeks of pregnancy). The number of children born prematurely each year is estimated at 15 million. The percentage of preterm births ranges 
between $5 \%$ and $18 \%$ of all births. Due to its multi-factor etiology, the problem remains a challenge in modern medicine and perinatal care, as it is associated with increased neonatal morbidity and mortality [1,2]. The risk of premature labor is increased e.g., in obese women. The association between obesity and preterm labor results from the increased risk of pregnancy complications in obese women, compared to those with a normal body weight [3]. In recent years, the prevalence of obesity (defined as a BMI $>30 \mathrm{~kg} / \mathrm{m}^{2}$ ) in women has increased considerably. Approximately $8 \%$ of women are now classified as severely (morbidly) obese, i.e., have a BMI $\geq 40 \mathrm{~kg} / \mathrm{m}^{2}$. According to estimates, the global prevalence of obesity in women is expected to exceed $21 \%$ by $2025[4,5]$. During pregnancy, maternal obesity poses risks both to the mother and the fetus, and significantly increases health care costs due to its association with a variety of obstetric conditions, including preterm labor $[3,6]$.

Threatened preterm labor is a challenge for the woman, who may experience strong emotions, such as anxiety, sadness, or guilt. Stress levels and ways of coping with stress in these circumstances depend on the structure of the woman's personality, the support she receives, and her psychosocial resilience resources [7]. Psychosocial resilience resources are intrapersonal and social characteristics of an individual that favor constructive responses to life's requirements and minimize the impact of any stressors experienced. These resources include self-efficacy, dispositional optimism, and health locus of control $[8,9]$. Self-efficacy is an individual's belief in their ability to achieve their goal through their own effort and perseverance. It is a determinant of health behaviors, it assists in coping with stress and pain, it facilitates the understanding of others' behaviors, and even stimulates immune system function [10]. During pregnancy and after delivery, it plays a major role in a woman's adaptation to the difficult and challenging role of a mother [11,12]. Dispositional optimism is a tendency to believe one will experience positive events in one's life. In difficult situations, it favors more active ways of coping [13]. Health locus of control refers to the belief that one has a real impact on one's health [14].

Pregnancy is a period of intense physiological and psychological change, entailing a number of adaptive processes. If the pregnancy is perceived by the woman as a threatening event, her adaptive mechanisms may be disrupted. This is certainly the case when pregnancy complications occur, including threatened preterm labor [15].

\section{Purpose of the Study}

The purpose of the study was to evaluate self-efficacy, life orientation, and health locus of control (psychosocial resilience resources) in pregnant women with obesity and threatened premature labor, and to identify the determinants of these variables.

\section{Materials and Methods}

\subsection{Study Groups}

The study was performed in the years 2017-2020 in a group of 328 pregnant women, hospitalized due to threatened preterm labor and diagnosed with obesity before the pregnancy in accordance with the World Health Organization's international classification, i.e., with a BMI equal to or exceeding $30 \mathrm{~kg} / \mathrm{m}^{2}$ [16].

Gestational age was identified based on the patients' medical records. In the study, the category of preterm labor was broken down into: extremely preterm (before 28 weeks), very preterm ( 28 to 32 weeks), and moderate to late preterm (32 to 37 weeks) [17]. A survey questionnaire was administered to each respondent on the last day of her hospitalization. Due to the scope of the study, the sample was selected in a targeted, rather than probabilistic manner. Inclusion criteria for the study group of pregnant patients were as follows: consent to participate in the study, age above 18 years (the legal age of majority in Poland), hospitalization at a high-risk pregnancy ward, gestational age between 22 and 37 weeks, obesity, Caucasian race, speaking Polish as one's native language, singleton pregnancy, and receiving proper prenatal care since the beginning of the pregnancy. The exclusion 
criteria were: unconfirmed gestational age, multiple pregnancy, or diagnosis of a lethal fetal anomaly (Figure 1).

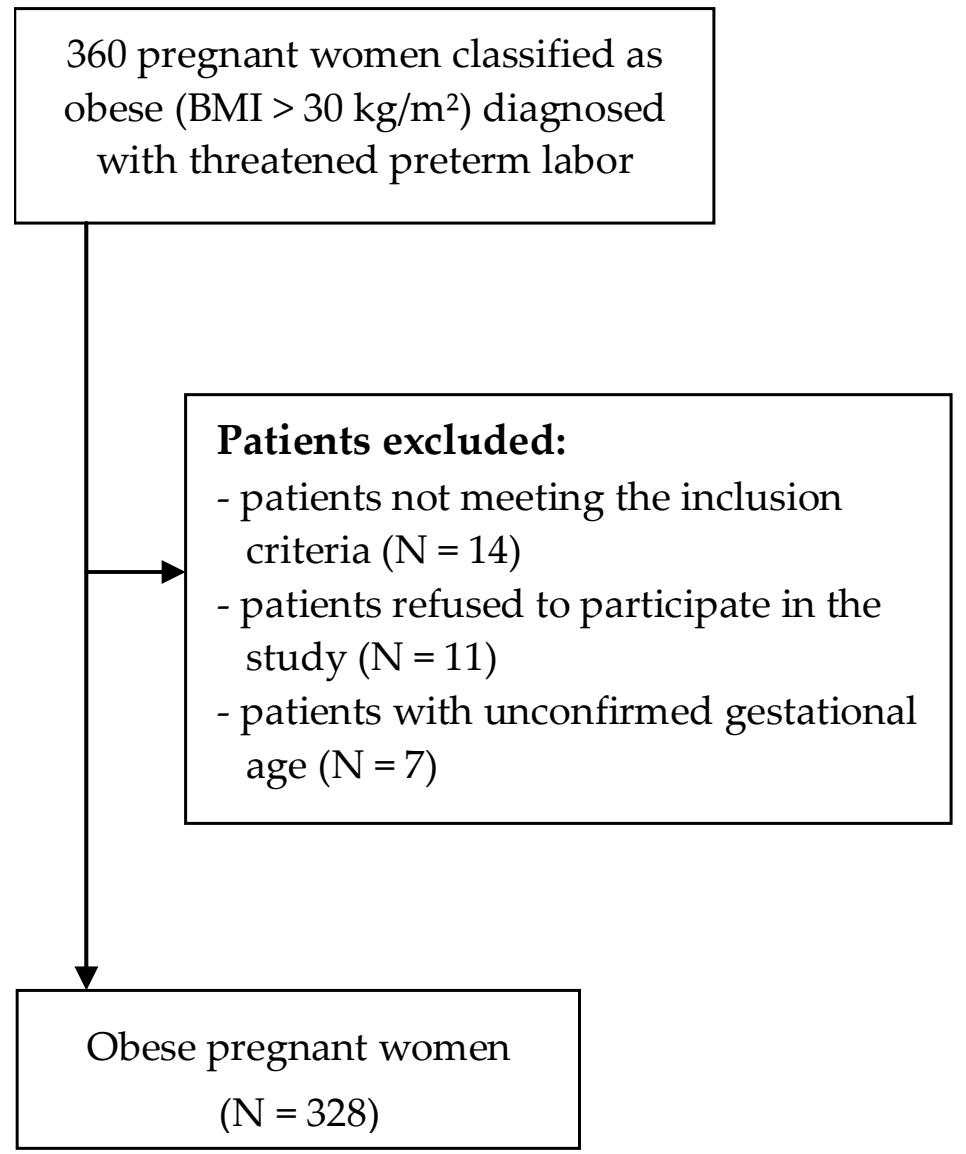

Figure 1. Flowchart of the recruitment process of the patients.

Table 1 shows the participants' characteristics. In the study group, most respondents were aged 26 -35 years $(57.9 \%)$, urban residents $(54.6 \%)$, married/in a stable relationship (72.3\%), had not completed higher education (51.2\%), and had a satisfactory socio-economic standing $(51.8 \%)$; typically, they were pregnant for the second time $(44.5 \%)$, nulliparous $(76.5 \%)$, between weeks 32 and 37 (36.3\%), and had chronic diseases (54.6\%).

The study was approved by the Lublin Medical University Bioethics Committee (approval no. KE-0254/284/2017). Each participant was informed about the purpose of the study and provided with questionnaire completion instructions. Respondents were informed that participation was voluntary, and that the study results were anonymous and to be used exclusively for research purposes. All respondents provided their informed consent in writing. Out of the 360 survey questionnaires distributed to respondents, 328 correctly completed questionnaires were analyzed, and the data effectiveness rate was $91.11 \%$. 
Table 1. Characteristics of women in the study.

\begin{tabular}{|c|c|c|c|}
\hline \multicolumn{2}{|c|}{ Characteristics of the Group } & \multirow{2}{*}{$\begin{array}{l}\mathbf{N} \\
95\end{array}$} & \multirow{2}{*}{\begin{tabular}{|c|}
$\%$ \\
29.0
\end{tabular}} \\
\hline & $18-25 \mathrm{y} / \mathrm{o}$ & & \\
\hline Age & $26-35 \mathrm{y} / \mathrm{o}$ & 190 & 57.9 \\
\hline & More than $35 \mathrm{y} / \mathrm{o}$ & 43 & 13.1 \\
\hline \multirow{2}{*}{ Residence } & Urban & 179 & 54.6 \\
\hline & Rural & 149 & 45.4 \\
\hline \multirow{2}{*}{ Relationship status } & Married & 237 & 72.3 \\
\hline & Single & 91 & 27.7 \\
\hline \multirow{2}{*}{ Education } & Other than higher & 168 & 51.2 \\
\hline & Higher & 160 & 48.8 \\
\hline \multirow{2}{*}{ Socio-economic standing } & Satisfying & 170 & 51.8 \\
\hline & Not satisfying & 158 & 48.2 \\
\hline \multirow{3}{*}{ Number of pregnancies } & First pregnancy & 132 & 40.2 \\
\hline & Second pregnancy & 146 & 44.5 \\
\hline & $\begin{array}{c}\text { Third or subsequent } \\
\text { pregnancy }\end{array}$ & 50 & 15.2 \\
\hline \multirow{3}{*}{ Number of previous deliveries } & None & 251 & 76.5 \\
\hline & One & 72 & 22.0 \\
\hline & Two or more & 5 & 1.5 \\
\hline \multirow{3}{*}{ Week of pregnancy } & 23-27 Hbd & 96 & 29.3 \\
\hline & $28-32 \mathrm{Hbd}$ & 113 & 34.5 \\
\hline & 32-37 Hbd & 119 & 36.3 \\
\hline \multirow{2}{*}{$\begin{array}{l}\text { Concurrent chronic disease: } \\
\text { hypertension, diabetes, thyroid } \\
\text { and heart diseases }\end{array}$} & No & 149 & 45.4 \\
\hline & Yes & 179 & 54.6 \\
\hline
\end{tabular}

\subsection{Assessments}

The study used a diagnostic survey with questionnaires. The following instruments were applied: The Life Orientation Test (LOT-R), the Generalized Self-Efficacy Scale (GSES), the Multidimensional Health Locus of Control Scale (MHLC), and a standardized interview questionnaire with items concerning the participants' characteristics.

The Generalized Self-Efficacy Scale (GSES) evaluates an individual's value system manifested in their ability to cope with difficult situations. The scale comprises 10 statements rated on a scale of 1 to 4 (1-disagree, 2-somewhat disagree, 3-somewhat agree, 4 -agree). The total score reflects the overall level of self-efficacy, with higher scores indicating more self-efficacy. Scores between 10 and 24 points are interpreted as a low level of self-efficacy, 25-29 points-moderate, and 30-40 points-a high level of self-efficacy. Cronbach's alpha for scale reliability is 0.85 , and the internal consistency of the GSES ranges between 0.76 and $0.91[18,19]$.

The Revised Life Orientation Test (LOT-R) evaluates the respondent's dispositional optimism based on 10 statements, six of which are diagnostic, while four are filler items. Each is rated on a five-item scale, from 0 -strongly disagree, to 4-strongly agree. Total scores range between 0 and 24 points. Scores of 17-24 points indicate a high level of dispositional optimism, 13-16-moderate optimism, and 0-12-a pessimistic disposition. Cronbach's alpha for the scale's internal consistency is 0.76 [20].

The Multidimensional Health Locus of Control Scale (MHLC) comprises 18 statements rated on a six-item scale, which represent convictions referring to generalized expectations in three health locus of control dimensions: internal factors (I am in control of my health), external factors/impact of others (my health results from the actions of others, including medical personnel), and the belief that one's health results from random events. The total score for each subscale is between 6 and 36 points. Higher scores indicate a stronger belief that the factor of interest affects one's health. Scores are interpreted based on the 
median value: those above the median are considered high, and those below the median are considered low. Scale reliability is 0.64 for internal control, 0.59 for impact of others, and 0.63 for random events [21].

\subsection{Statistical Analysis}

Statistical analysis of the material collected was performed using Statistica software, version 12.5. In the descriptive analysis, means and SD values, frequencies, and percentages were calculated. Stepwise regression was used to identify predictors of LOT-R, GSES, and MHLC scores. Stepwise regression is a method of regression model fitting in which the choice of predictive variables is performed using an automatic procedure. For the purpose of this analysis, dummy coding was used for variables such as residence, education, or support from loved ones. Correlations between quantitative variables were calculated. Linearity assumptions and variance homogeneity were tested with scatter plots, and there was no heteroscedasticity. Multicollinearity was measured by the variance inflation factor (VIF). For the goodness of model fit, adjusted R-squared and overall F-test were considered. P-values below 0.05 were used to identify independently associated factors in multivariate linear regressions.

\section{Results}

Table 2 reports the mean scores among the women with threatened preterm labor for generalized self-efficacy $(28.02 \pm 3.67)$, dispositional optimism $(16.20 \pm 3.95)$, and health locus of control (MHLC) broken down into internal factors (26.08 \pm 3.68$)$, impact of others $(21.52 \pm 4.06)$, and belief that one's health is determined by random events $(19.08 \pm 5.36)$.

Table 2. Generalized self-efficacy, dispositional optimism, and health locus of control scores in obese pregnant women with threatened preterm labor.

\begin{tabular}{|c|c|c|c|c|c|c|}
\hline \multicolumn{2}{|c|}{ Resilience Resources } & $\mathbf{M}$ & Me & SD & Min & $\operatorname{Max}$ \\
\hline \multicolumn{2}{|r|}{ GSES } & 28.02 & 28.00 & 3.67 & 15.00 & 38.00 \\
\hline \multicolumn{2}{|r|}{ LOT R } & 16.20 & 17.00 & 3.95 & 4.00 & 24.00 \\
\hline \multirow{3}{*}{ MHLC } & Internal & 26.08 & 27.00 & 3.68 & 15.00 & 36.00 \\
\hline & Impact of others & 21.52 & 22.00 & 4.06 & 10.00 & 31.00 \\
\hline & Random events & 19.08 & 19.00 & 5.36 & 6.00 & 32.00 \\
\hline
\end{tabular}

GSES-Generalized Self-Efficacy Scale; LOT-R—Life Orientation Test-Revised; MHLC-Multidimensional Health Locus of Control Scale.

Our statistical analysis demonstrated significant positive correlations between the respondents' sense of generalized self-efficacy on the one hand and their dispositional optimism and internal health locus of control on the other, and between dispositional optimism and internal health locus of control. The correlations were rated at between 0.129 and 0.479 . There were also negative correlations between the women's generalized self-efficacy and their health locus of control in the external factors and random events dimensions, as well as between attribution of health locus of control to external factors and to random events. The strength of correlations was between -0.434 and -0.120 (Table 3).

Table 4 reports regression analysis results for generalized self-efficacy (GSES), and dispositional optimism (LOT-R) scores in the women studied. Statistically significant predictors for the self-efficacy variable model included: satisfactory socio-economic standing $(\beta=0.156 ; p=0.004)$, being nulliparous $(\beta=-0.191 ; p=0.002)$, and the absence of comorbidities $(\beta=-0.145 ; p=0.008)$. Multilevel variable scanning showed higher levels of dispositional optimism in women who were married $(\beta=0.381 ; p=0.000)$, reported a satisfactory socio-economic standing $(\beta=0.137 ; p=0.005)$, were between 23 and 27 weeks pregnant $(\beta=-0.231 ; p=0.000)$, and had no chronic comorbidities $(\beta=-0.129 ; p=0.009)$. 
Table 3. Correlations between GSES, LOT-R, and MHLC scores in pregnant women with obesity and threatened preterm labor.

\begin{tabular}{|c|c|c|c|c|c|c|}
\hline & & \multirow{2}{*}{ GSES } & \multirow{2}{*}{ LOT-R } & \multicolumn{3}{|c|}{ MHLC } \\
\hline & & & & Internal & $\begin{array}{c}\text { Impact of } \\
\text { Others }\end{array}$ & $\begin{array}{c}\text { Random } \\
\text { Events }\end{array}$ \\
\hline & GSES & - & & & & \\
\hline & LOT-R & $0.479 * *$ & - & & & \\
\hline \multirow{3}{*}{ MHLC } & Internal & $0.365^{* *}$ & $0.129 *$ & - & & \\
\hline & Impact of others & $-0.149 * *$ & 0.062 & 0.099 & - & \\
\hline & Random events & $-0.120 *$ & $-0.434^{* *}$ & -0.032 & $-0.125 *$ & - \\
\hline
\end{tabular}

GSES-Generalized Self-Efficacy Scale; LOT-R—Life Orientation Test-Revised; MHLC—Multidimensional Health Locus of Control Scale. ${ }^{*} p<0.05 ;{ }^{* *} p<0.01$.

Table 4. Regression analysis results for GSES and LOT-R scores in obese pregnant women with threatened preterm labor.

\begin{tabular}{|c|c|c|c|c|c|c|c|c|c|c|}
\hline \multirow{2}{*}{ Predictors } & \multicolumn{5}{|c|}{$\begin{array}{c}\text { GSES } \\
\mathrm{F}=3.888 ; p<0.001 ; \mathrm{R}^{2}=0.074\end{array}$} & \multicolumn{5}{|c|}{$\begin{array}{c}\text { LOT-R } \\
\mathrm{F}=12.890 ; p<0.001 ; \mathrm{R}^{2}=0.247\end{array}$} \\
\hline & $B$ & $S E$ & $\beta$ & $t$ & $p$ & $B$ & $S E$ & $\beta$ & $t$ & $p$ \\
\hline Age & -0.033 & 0.314 & -0.006 & -0.106 & 0.916 & 0.433 & 0.304 & 0.069 & 1.422 & 0.156 \\
\hline Residence ${ }^{\mathrm{A}}$ & 0.660 & 0.403 & 0.090 & 1.639 & 0.102 & -0.023 & 0.390 & -0.003 & -0.059 & 0.953 \\
\hline Relationship status B & 0.734 & 0.445 & 0.090 & 1.648 & 0.100 & 3.349 & 0.431 & 0.381 & 7.763 & 0.000 \\
\hline Socio-economic standing $\mathrm{C}$ & 1.146 & 0.399 & 0.156 & 2.876 & 0.004 & 1.084 & 0.386 & 0.137 & 2.808 & 0.005 \\
\hline Education ${ }^{\mathrm{D}}$ & 0.014 & 0.402 & 0.002 & 0.036 & 0.971 & 0.130 & 0.389 & 0.016 & 0.333 & 0.739 \\
\hline Number of pregnancies $\mathrm{E}$ & 0.720 & 0.454 & 0.096 & 1.586 & 0.114 & -0.514 & 0.440 & -0.064 & -1.169 & 0.243 \\
\hline $\begin{array}{c}\text { Number of previous } \\
\text { deliveries } F\end{array}$ & -1.650 & 0.520 & -0.191 & -3.174 & 0.002 & -0.267 & 0.503 & -0.029 & -0.530 & 0.597 \\
\hline Week of pregnancy & -0.364 & 0.250 & -0.080 & -1.460 & 0.145 & -1.129 & 0.242 & -0.231 & -4.669 & 0.000 \\
\hline $\begin{array}{l}\text { Occurrence of chronic } \\
\text { diseases: }\end{array}$ & -1.068 & 0.402 & -0.145 & -2.658 & 0.008 & -1.020 & 0.389 & -0.129 & -2.621 & 0.009 \\
\hline
\end{tabular}

GSES-Generalized Self-Efficacy Scale; LOT-R—Life Orientation Test-Revised; $\beta$ —standardized coefficients. SE—bootstrapped standard errors. Reference categories: ${ }^{\mathrm{A}}$ residence-rural; ${ }^{\mathrm{B}}$ married; ${ }^{\mathrm{C}}$ satisfactory socio-economic standing; ${ }^{\mathrm{D}}$ higher education; ${ }^{\mathrm{E}}$ second or subsequent pregnancy; ${ }^{\mathrm{F}}$ at least one previous delivery; ${ }^{\mathrm{G}}$ chronic disease.

The regression model for the health locus of control (MHLC) variable is shown in Table 5. External locus of control was positively associated with being married $(\beta=0.115$; $p=0.040)$, having a satisfactory socio-economic standing $(\beta=0.121 ; p=0.030)$, and having given birth at least once before $(\beta=0.124 ; p=0.044)$. Higher scores for the "random events" locus of control variable were recorded for women who were single $(\beta=-0.281$; $p=0.0001)$, had an unsatisfactory socio-economic standing $(\beta=-0159 ; p=0.002)$, were 32 weeks pregnant $(\beta=0.227 ; p=0.000)$, and lived in rural areas $(\beta=0.115 ; p=0.027)$. In the case of the internal health locus of control variable, the proposed regression model had a poor fit to the data $(\mathrm{F}=1.692 ; p=0.090)$. 
Table 5. Regression analysis results for MHLC scores in pregnant women with threatened preterm labor.

\begin{tabular}{|c|c|c|c|c|c|c|c|c|c|c|}
\hline \multirow[t]{2}{*}{ Predictors } & \multicolumn{5}{|c|}{$\begin{array}{c}\text { MHLC-Impact of Others } \\
\mathrm{F}=2.258 ; p=0.018 ; \mathrm{R}^{2}=0.033\end{array}$} & \multicolumn{5}{|c|}{$\begin{array}{c}\text { MHLC-Random Events } \\
\mathrm{F}=7.986 ; p<0.001 ; \mathrm{R}^{2}=0.161\end{array}$} \\
\hline & $B$ & $S E$ & $\beta$ & $t$ & $p$ & $B$ & $S E$ & $\beta$ & $t$ & $p$ \\
\hline Age & -0.028 & 0.355 & -0.004 & -0.079 & 0.937 & -0.433 & 0.436 & -0.051 & -0.992 & 0.322 \\
\hline Residence ${ }^{\mathrm{A}}$ & -0.256 & 0.455 & -0.031 & -0.562 & 0.575 & 1.240 & 0.559 & 0.115 & 2.216 & 0.027 \\
\hline Relationship status ${ }^{B}$ & 1.038 & 0.503 & 0.115 & 2.064 & 0.040 & -3.359 & 0.619 & -0.281 & -5.431 & 0.000 \\
\hline Socio-economic standing ${ }^{\mathrm{C}}$ & 0.984 & 0.450 & 0.121 & 2.186 & 0.030 & -1.708 & 0.554 & -0.159 & -3.085 & 0.002 \\
\hline Education $\mathrm{D}$ & 0.270 & 0.454 & 0.033 & 0.594 & 0.553 & 0.002 & 0.558 & 0.000 & 0.004 & 0.997 \\
\hline Number of pregnancies $E$ & 0.230 & 0.513 & 0.028 & 0.448 & 0.654 & -0.204 & 0.630 & -0.019 & -0.323 & 0.747 \\
\hline $\begin{array}{c}\text { Number of previous } \\
\text { deliveries } F\end{array}$ & 1.189 & 0.587 & 0.124 & 2.024 & 0.044 & -0.995 & 0.722 & -0.079 & -1.378 & 0.169 \\
\hline Week of pregnancy & 0.074 & 0.282 & 0.015 & 0.263 & 0.793 & 1.506 & 0.347 & 0.227 & 4.344 & 0.000 \\
\hline $\begin{array}{l}\text { Occurrence of chronic } \\
\text { diseases: } \mathrm{G}\end{array}$ & 0.572 & 0.454 & 0.070 & 1.259 & 0.209 & 0.710 & 0.558 & 0.066 & 1.271 & 0.205 \\
\hline
\end{tabular}

MHLC—Multidimensional Health Locus of Control Scale; $\beta$-standardized coefficients. SE-bootstrapped standard errors. Reference categories: ${ }^{\mathrm{A}}$ residence- rural; $^{\mathrm{B}}$ married; ${ }^{\mathrm{C}}$ satisfactory socio-economic standing; ${ }^{\mathrm{D}}$ higher education; ${ }^{\mathrm{E}}$ second or subsequent pregnancy;

$\mathrm{F}$ at least one previous delivery; ${ }^{\mathrm{G}}$ chronic disease.

\section{Discussion}

Pregnant women with obesity have a higher incidence of obstetric complications such as miscarriage, pregnancy-induced hypertension, preeclampsia, and eclampsia [22-25]. In addition, maternal obesity is associated with a higher risk of preterm labor, which, according to Slack et al. [26], increases along with the degree of obesity. Threatened preterm labor is a major challenge for a woman, which causes chronic stress and fear for oneself and one's baby, and requires hospitalization. An individual's way of coping with difficulties and their perception of stress are influenced, among other factors, by their psychosocial resilience resources [7].

The purpose of the present study was to assess the level of such psychosocial resilience resources as self-efficacy, dispositional optimism, and health locus of control in pregnant women with obesity and threatened premature labor, as well as the determinants of these resources.

Self-efficacy relies on a cognitive process whereby an individual evaluates their ability to handle a variety of situations. Research to date indicates that it is an important predictor of the attitudes, emotions, and behaviors of pregnant women $[27,28]$. However, the literature on the subject is limited. The present study broadens the understanding of the topic and is among the first ever to analyze generalized sense of self-efficacy (GSES scores) among obese pregnant women with threatened premature labor. The mean GSES score was 28.02, within the upper limits of the mean reference value range. Similar findings were reported in studies on primigravid women in the third trimester of pregnancy (28.29) [29], in pregnant women with hyperglycemia (31.58) [30], and in women who had miscarried (30.29) [31].

Significant GSES predictors in the present study included: a satisfactory socio-economic standing, being nulliparous, and the absence of chronic diseases. In the study by Brunton et al. [32], self-efficacy among mothers was correlated with acceptance of pregnancy, but, as in the present study, was uncorrelated with age. Soh et al. [33] found higher self-efficacy in multiparous women reporting better psychological wellbeing, and lower in those who had delivered by cesarean section and had more labor-related anxiety. In others studies, self-efficacy was also reported as a predictor of such health-related behaviors in pregnant women as avoidance of second-hand smoke [34] or good oral hygiene [35], but also of concern for the child and attitudes towards medical personnel and towards labor [32]. Women who have delivered healthy children at term and have a high level of self-efficacy tend to view their parental competence more favorably and be more satisfied with perinatal care $[11,12]$. 
A moderate level of self-efficacy may enable women experiencing a threat to pregnancy to assess their situation accurately and seek effective ways of dealing with the difficulties and obstacles they encounter-in this case, the risk of a preterm delivery and its potential consequences. They may also be expected to be more involved in the treatment process, showing better compliance and adherence, e.g., by resting more, avoiding exertion and stress, and abstaining from substance use.

Dispositional optimism is a tendency to believe one will experience positive events in one's life. Optimistically disposed individuals demonstrate more active coping strategies, lower levels of psychological stress, positive health-related behaviors, and better physical functioning, among other characteristics [36]. In our study, the pregnant women with threatened premature labor had a moderate level of dispositional optimism. Moyer et al. [37] studied dispositional optimism and health-related quality of life in pregnant women and found higher levels of optimism in respondents who were better educated, professionally active, and without pregnancy complications. Loh et al. [38] found that higher levels of optimism were correlated with positive health-related behaviors, lower levels of parental stress, and better quality of life in the mothers studied.

In our study, being married was significantly associated with dispositional optimism. Patients who are supported by their partners tend to perceive their own future in a more positive manner, even in a difficult situation, such as that of hospitalization. In this context, the study by Giangiordano et al. [13] is also of interest, as the authors found higher levels of dispositional optimism in pregnant women to be associated with such variables as age (30 or above), being in a relationship (married or in a stable informal relationship), and education (high school or higher).

We found an association between dispositional optimism in pregnant women with threatened premature labor and earlier gestational week. Notably, the need to be hospitalized during pregnancy represents a major challenge for a woman. During hospitalization, pregnant patients undergo frequent examinations, have to remain immobilized during infusions or cardiotocography, and may be placed on bed rest. In addition, their wellbeing may be impaired by medication, e.g., tocolytics. These patients live in constant fear and uncertainty as to whether all these treatments and sacrifices will allow them to achieve their goal, i.e., give birth to a healthy baby. Dispositional optimism moderates a factual assessment of the situation, and increases the woman's motivation, perseverance, and determination.

Another psychosocial resilience resource analyzed in the present study was health locus of control. Individuals with an internal locus of control have a sense of control over their own health and are thus likely to take specific measures to improve or maintain it. In turn, those with an external locus of control believe that, regardless of their own actions, things are decided by external factors. Therefore, they are convinced that health-promoting behaviors are ineffectual, and thus tend not to engage in actions to maintain or improve their health. Health locus of control may also be attributed to random events. In this case, one has no sense of control over their health, which interferes with health-promoting behaviors $[19,39]$. Out of all health locus of control dimensions, the highest scores were obtained on the internal control subscale. The tendency to place the health locus of control internally is desirable in pregnant women, as a conviction about being in control of one's health promotes positive health-related behaviors (such as proper nutrition, avoidance of substance use, reduction/avoidance of stress, hygienic lifestyle, regular medical checkups), thus limiting the risk factors for various pregnancy complications $[39,40]$. Kordi et al. [41] demonstrated a positive correlation between taking control of one's own health and self-care activities.

Threatened preterm labor is a stressful situation which entails a number of challenges for a woman, and therefore entrusting control of one's health to others, including medical personnel, may support treatment aimed at prolonging the pregnancy and limiting the consequences of preterm birth. Our findings indicate that the perception of one's health as dependent on external factors is more common among women who are married, satisfied 
with their living and financial situation, and nulliparous. Women who attribute their health to the impact of others are more likely to rely on the opinion of specialists and seek sources of support to help them cope with the situation. This is corroborated by Kordi et al., [41] who demonstrated that pregnant women with gestational diabetes mellitus attributed control over their health mostly to others. This seems positive as all pregnancy complications require the patient to comply with recommendations from the medical staff.

In the group of pregnant women with obesity that was studied, the conviction that one's health is dependent on random events was more common in those who had an unsatisfactory socio-economic standing and lived in rural areas. Patients with such an outlook tend to be more passive in their health-related behaviors, and are not particularly consistent in adhering to medical recommendations or undergoing regular diagnostics. This may be assumed to result from a lack of consistency in adhering to recommendations and undergoing regular diagnostics in patients who are not convinced of their ability to actively modify their own health [39-41]. As these women's motivation is low, they are not proactive in their health-related behaviors and are unlikely to follow professional advice on health; therefore, these patients will require longer and more intensive health education interventions.

Care for women with obesity and threatened preterm labor should include interventions to reinforce their self-efficacy, which fosters adaptation to one's current health situation. The appropriate management of pregnant patients should not only focus on health or economic benefits-it should also include an evaluation of the patients' psychosocial resilience resources that favor constructive coping with one's life situation and its requirements, and minimize the impact of stressors the patients encounter. Our study is the first that we know of to analyze self-efficacy, life orientation, and health locus of control in pregnant women with obesity diagnosed with threatened premature labor. Notably, we used standardized instruments, and so other researchers interested in issues related to premature labor will be able to compare results, continue in-depth research, and draw conclusions. The results obtained here may help clarify the importance of care going beyond professional medical interventions and including strategies of holistic care for pregnant women with threatened premature labor. The appropriate behaviors of medical personnel, education, and support may all contribute to the optimization of obstetric care and positively affect the psycho-physical condition of women with threatened premature labor.

\section{Conclusions}

Obese women with threatened premature labor have a moderate level of generalized self-efficacy, a moderate level of dispositional optimism, and an internal health locus of control.

Generalized self-efficacy in obese women with threatened preterm labor is associated with a satisfactory socio-economic standing, being nulliparous, and the absence of chronic disease.

Dispositional optimism in obese pregnant women with threatened preterm labor is determined by their marital status, socio-economic standing, gestational age, and the absence of comorbidities.

Being married, having a satisfactory socio-economic standing, and having given birth at least once before are factors positively associated with an external health locus of control, while a locus of control attributed to random events is determined by the woman's marital status, socio-economic standing, residence, and gestational age. 
Author Contributions: A.B.: conceptualization, methodology, data collection, writing -original draft preparation; E.R.: conceptualization, methodology, writing-original draft preparation; J.G.-G.: data collection, data analysis, writing-original draft preparation; A.P.: data collection, data analysis, writing-original draft preparation; E.H.: writing-reviewing and editing; M.M.: methodology, data collection; G.I.-P.: writing-reviewing and editing; A.W.: interpreted the data and carried out a critical review of the manuscript. All authors have read and approved the final manuscript. All authors have read and agreed to the published version of the manuscript.

Funding: This research received no external funding.

Institutional Review Board Statement: The study was conducted according to the guidelines of the Declaration of Helsinki, and approved by the Institutional Review Board (or Ethics Committee) of LUBLIN MEDICAL UNIVERSITY (protocol code KE-0254/284/2017).

Informed Consent Statement: Informed consent was obtained from all subjects involved in the study.

Data Availability Statement: The datasets generated during and/or analysed during the current study are available from the corresponding author on reasonable request.

Conflicts of Interest: The authors declare no conflict of interest.

\section{References}

1. Liu, L.; Oza, S.; Hogan, D.; Chu, Y.; Perin, J.; Zhu, J.; Lawn, J.E.; Cousens, S.; Mathers, C.; Black, R.E. Global, regional, and national causes of under-5 mortality in 2000-15: An updated systematic analysis with implications for the Sustainable Development Goals. Lancet 2016, 388, 3027-3035. [CrossRef]

2. Delnord, M.; Zeitlin, J. Epidemiology of late preterm and early term births-An international perspective. Semin. Fetal Neonatal Med. 2019, 24, 3-10. [CrossRef] [PubMed]

3. Cnattingius, S.; Villamor, E.; Johansson, S.; Bonamy, A.-K.E.; Persson, M.; Wikström, A.-K.; Granath, F. Maternal obesity and risk of preterm delivery. JAMA 2013, 309, 2362-2367. [CrossRef] [PubMed]

4. NCD Risk Factor Collaboration. Worldwide trends in bodymass index, underweight, overweight, and obesity from 1975 to 2016 : A pooled analysis of 2416 population-based measurement studies in 128.9 million children, adolescents, and adults. Lancet 2017, 390, 2627-2642. [CrossRef]

5. $\quad$ Black, R.E.; Victora, C.G.; Walker, S.P.; Bhutta, Z.A.; Christian, P.; De Onis, M.; Ezzati, M.; Grantham-McGregor, S.; Katz, J.; Martorell, R.; et al. Maternal and child undernutrition and overweight in low-income and middle-income countries. Lancet 2013, 382, 427-451. [CrossRef]

6. World Health Organization. World Health Statistics 2019. Available online: https://www.who.int/gho/publications/world_ health_statistics/2019/EN_WHS_2019_Main.pdf. (accessed on 24 October 2020).

7. McDonald, S.; Kingston, D.; Bayrampour, H.; Dolan, S.; Tough, S. Cumulative psychosocial stress, coping resources, and preterm birth. Archiv. Womens Ment. Health 2014, 17, 559-568. [CrossRef] [PubMed]

8. Hobfoll, S.E.; Tirone, V.; Holmgreen, L.; Gerhart, J. Conservation of resources theory applied to major stress. In Stress: Concepts, Cognition, Emotion, and Behaviour; Fink, G., Ed.; Elsevier Academic Press: London, UK, 2016; Volume 1, pp. 65-71.

9. Niessen, C.; Jimmieson, N. Threat of Resource Loss: The Role of Self-Regulation in Adaptive Task Performance. J. Appl. Psych. 2016, 101, 450-462. [CrossRef]

10. Schönfeld, P.; Preusser, F.; Margraf, J. Costs and benefits of self-efficacy: Differences of the stress response and clinical implications. Neurosci. Biobehav. Rev. 2017, 75, 40-52. [CrossRef] [PubMed]

11. Shorey, S.; Chan, S.; Chong, Y.; He, H. Predictors of Maternal Parental Self-Efficacy Among Primiparas in the Early Postnatal Period. West. J. Nurs. Res. 2015, 37, 1604-1622. [CrossRef] [PubMed]

12. Wheeler, S.; Maxson, P.; Truong, T.; Swamy, G. Psychosocial Stress and Preterm Birth: The Impact of Parity and Race. Matern. Child. Health J. 2018, 22, 1430-1435. [CrossRef]

13. Giangiordano, I.; Sahani, H.; Di Mascio, D.; Saccone, G.; Bellussi, F.; Berghella, A.; Braverman, A.; Berghella, V. Optimism during pregnancy and obstetrical outcomes: A systematic review. Eur. J. Obstet. Gynecol. Reprod. Biol. 2020, 248, 95-101. [CrossRef]

14. Rosińska, P. Poczucie własnej skuteczności i lokalizacja kontroli zdrowia jako predyktory troski o zdrowie w grupie matek małych dzieci. FetR 2017, 4, 113-142.

15. Suff, N.; Story, L.; Shennan, A.H. The prediction of preterm delivery: What is new? Semin. Fetal Neonatal Med. 2019, 24, 27-32. [CrossRef] [PubMed]

16. World Health Organisation. Global Database on Body Mass Index: BMI Classification 2006. Available online: http:/ /apps.who. int/bmi/index.jsp?introPage \protect\$relax \protect $\{\backslash$ begingroup1 \endgroup \@@over4\}\$intro_3.html (accessed on 24 October 2020).

17. Tucker, J.; McGuire, W. Epidemiology of preterm birth. BMJ 2004, 329, 675-678. [CrossRef] [PubMed] 
18. Schwarzer, R.; Jerusalem, M.; Juczyński, Z. Skala Uogólnionej Własnej Skuteczności-GSES. In Narzędzia Pomiaru w Promocji i Psychologii Zdrowia; Juczyński, Z., Ed.; Pracownia Testów Psychologicznych Polskiego Towarzystwa Psychologicznego: Warszawa, Poland, 2012; pp. 89-94.

19. Lonnfjord, V.; Hagquist, C. The psychometric properties of the Swedish version of the general self-efficacy scale: A Rasch analysis based on adolescent data. Curr. Psychol. 2018, 37, 703-715. [CrossRef]

20. Scheier, M.F.; Carver, C.S.; Bridges, M.W. Test Orientacji Życiowej-LOT-R. In Narzędzia Pomiaru w Promocji i Psychologii Zdrowia; Juczyński, Z., Ed.; Pracownia Testów Psychologicznych Polskiego Towarzystwa Psychologicznego: Warszawa, Poland, 2012; pp. 61-66.

21. Wallston, K.A.; Wallston, B.S.; DeVellis, R. Wielowymiarowa Skala Umiejscowienia Kontroli Zdrowia-MHLC. In Narzędzia Pomiaru w Promocji i Psychologii Zdrowia; Juczyński, Z., Ed.; Pracownia Testów Psychologicznych Polskiego Towarzystwa Psychologicznego: Warszawa, Poland, 2012; pp. 81-88.

22. Lawn, J.E.; Blencowe, H.; Waiswa, P.; Amouzou, A.; Mathers, C.; Hogan, D.; Flenady, V.; Frøen, J.F.; Qureshi, Z.U.; Calderwood, C.; et al. Stillbirths: Rates, risk factors, and acceleration towards 2030. Lancet 2016, 377, 587-603. [CrossRef]

23. Amark, H.; Westgren, M.; Persson, M. Prediction of stillbirth in women with overweight or obesity-A register-based cohort study. PLoS ONE 2018, 13, e0206940. [CrossRef]

24. Liu, B.; Xu, G.; Sun, Y.; Du, Y.; Gao, R.; Snetselaar, L.G.; Santillan, M.K.; Bao, W. Association between maternal pre-pregnancy obesity and preterm birth according to maternal age and race or ethnicity: A population-based study. Lancet Diabetes Endocrinol. 2019, 7, 707-714. [CrossRef]

25. Kim, S.S.; Zhu, Y.; Grantz, K.L.; Hinkle, S.N.; Chen, Z.; Wallace, M.E.; Smarr, M.M.; Epps, N.M.; Mendola, P. Obstetric and Neonatal Risks Among Obese Women Without Chronic Disease. Obstet. Gynecol. 2016, 128, 104-112. [CrossRef]

26. Slack, E.; Best, K.E.; Rankin, J.; Heslehurst, N. Maternal obesity classes, preterm and post-term birth: A retrospective analysis of 479,864 births in England. BMC Pregnancy Childbirth 2019, 19, 434. [CrossRef]

27. Razurel, C.; Kaiser, B.; Antonietti, J.P.; Epiney, M.; Sellenet, C. Relationship between perceived perinatal stress and depressive symptoms, anxiety, and parental self-efficacy in primiparous mothers and the role of social support. Women Health 2017, 57, 154-172. [CrossRef] [PubMed]

28. Wernand, J.J.; Kunseler, F.C.; Oosterman, M.; Beekman, A.T.; Schuengel, C. Prenatal changes in parenting self-efficacy: Linkages with anxiety and depressive symptoms in primiparous women. Inf. Ment. Health J. 2014, 35, 42-50. [CrossRef] [PubMed]

29. Lowe, N.K. Self-efficacy for labor and childbirth fears in nulliparous pregnant women. J. Psychosom. Obstet. Gynaecol. 2000, 21, 219-224. [CrossRef] [PubMed]

30. Iwanowicz-Palus, G.; Zarajczyk, M.; Pięta, B.; Bień, A. Quality of Life, Social Support, Acceptance of Illness, and Self-Efficacy among Pregnant Women with Hyperglycemia. Int. J. Environ. Res. Public Health. 2019, 16, 3941. [CrossRef]

31. Iwanowicz-Palus, G.; Mróz, M.; Bień, A. Quality of life, social support and self-efficacy in women after a miscarriage. Health Qual. Life Outcomes 2021, 19, 1-8. [CrossRef]

32. Brunton, R.; Simpson, N.; Dryerm, R. Pregnancy-Related Anxiety, Perceived Parental Self-Efficacy and the Influence of Parity and Age. Int. J. Environ. Res. Public Health 2020, 17, 6709. [CrossRef]

33. Soh, Y.X.; Razak, N.K.B.A.; Cheng, L.J.; Lau, Y. Determinants of childbirth self-efficacy among multi-ethnic pregnant women in Singapore: A structural equation modelling approach. Midwifery 2020, 87, 102716. [CrossRef]

34. Mazloomy Mahmoodabad, S.S.; Karimiankakolaki, Z.; Kazemi, A.; Fallahzadeh, H. Self-efficacy and perceived barriers of pregnant women regarding exposure to second-hand smoke at home. J. Educ. Health Promot. 2019, 29, 139. [CrossRef]

35. Jamieson, L.M.; Parker, E.J.; Roberts-Thomson, K.F.; Lawrence, H.P.; Broughton, J. Self-efficacy and self-rated oral health among pregnant aboriginal Australian women. BMC Oral Health 2014, 14, 29. [CrossRef]

36. James, P.; Kim, E.S.; Kubzansky, L.D.; Zevon, E.S.; Trudel-Fitzgerald, C.; Grodstein, F. Optimism and Healthy Aging in Women. Am. J. Prev. Med. 2019, 56, 116-124. [CrossRef]

37. Moyer, C.A.; Yang, H.; Kwawukume, Y.; Gupta, A.; Zhu, Y.; Koranteng, I.; Elsayed, Y.; Wei, Y.; Greene, J.; Calhoun, C.; et al. Optimism/pessimism and health-related quality of life during pregnancy across three continents: A matched cohort study in China, Ghana, and the United States. BMC Pregnancy Childbirth 2009, 9, 39. [CrossRef]

38. Loh, J.; Harms, C.; Harman, B. Effects of Parental Stress, Optimism, and Health-Promoting Behaviors on the Quality of Life of Primiparous and Multiparous Mothers. Nurs. Res. 2017, 66, 231-239. [CrossRef] [PubMed]

39. Puente, C.; Morales, D.; Monge, F. Religious Coping and Locus of Control in Normal Pregnancy: Moderating Effects Between Pregnancy Worries and Mental Health. J. Relig. Health 2015, 54, 1598-1611. [CrossRef]

40. Ashford, K.; Rayens, M. Ethnicity, smoking status, and preterm birth as predictors of maternal locus of control. Clin. Nurs. Res. 2015, 24, 172-187. [CrossRef] [PubMed]

41. Kordi, M.; Heravan, M.B.; Asgharipour, N.; Akhlaghi, F.; Mazloum, S.R. Does maternal and fetal health locus of control predict self-care behaviors among women with gestational diabetes? J. Edu. Health Promot. 2017, 6, 73. [CrossRef] 